Р.В. Лященко ${ }^{1}$, Д.О. Кузнєцов ${ }^{2}$, О.В. Повещенко ${ }^{2}$ В.В. Козін ${ }^{2}$, Д.В. Стасенко ${ }^{2}$

${ }^{1}$ Харківський національний університет Повітряних Сил ім. І. Кожедуба, Харків

${ }^{2}$ Національний університет оборони України ім. I. Черняховського, Київ

\title{
РОЗПОДІЛЕНА СИСТЕМА ЗБОРУ, ОБРОБКИ, ЗБЕРІГАННЯ І ПОШУКУ ГЕОПРОСТОРОВИХ ДАНИХ ПРИ ВЕДЕННІ ГЕОПРОСТОРОВОЇ РОЗВІДКИ
}

Розглядаються особливості мережецентричних систем, щио підвищують ефективність процесів збору, зберігання та пошуку геопросторових даних при веденні геопросторової розвідки, як прогресивного та перспективного технічного виду воєнної розвідки Украӥни. Розроблена концепція створення розподіленої системи збору, зберігання і пошуку геопросторових даних. Запропоновано типову структуру геопросторових даних, щзо обробляються в територіально-розподілених базах. Розроблений алгоритм розподіленого пошуку геоданих в каталогах з моделлю управління доступом до геопросторових даних.

Ключові слова: бази даних, геодані, геопросторова розвідка, мережецентричні системи, метадані.

\section{Вступ}

Постановка проблеми. Високі темпи сучасного розвитку космічних засобів і технологій дистанційного зондування Землі (ДЗ3) сприяють широкому застосуванню геопросторових даних при вирішенні різних завдань. В Збройних Силах України набуваєрозвитку геопросторова розвідка, яка обробляє дані отримані від різних джерел, застосовувуючи геоінформаційний підхід, сутність якого полягає у систематизації і об'єднанні інформації про об'єкт розвідки, отриманої з різних джерел, та відображені іiї в єдиній просторово-часовій системі координат [1-2]. Склад інформації, що необхідна для прийняття рішення, все більше нагадує декількарівневий пиріг до якого постійно добавляються додаткові рівні (слої) - види даних, що використовуються. Крім даних про місцевість росте потік неструктурованої або слабко структурованої інформації, що використовується в процесі прийняття рішення, яку необхідно аналізувати та враховувати. Аналіз характеру сучасних воєнних конфліктів, вказують на те, що основним видом даних, що обробляються, є геопросторові дані. Можна стверджувати, що 80 відсотків інформаційних ресурсів мають координату прив'язку [3-4].

Під геопросторовими даними розуміють дані про географічні обєкти, які є формалізованими цифровими моделями матеріальних або ідеальних (абстрактних) об'єктів реального або віртуального світу. Повний цифровий опис просторового об'єкта і зміст просторових даних складується 3 ідентифікатора об’єкту, набору його атрибутів (властивостей, характеристик) з їх значеннями і параметрів локалізації об’єкту в просторі та часі (в деякій системі просторово-часових координат). Правила цифрового моделювання об’єктів реальності шляхом опису типів та властивостей елементарних просторових об'єктів, їх наборів та міжоб'єктних відносин називають моделлю просторових даних $[1 ; 5]$.

На сьогоднішній день об'єми геопросторових даних, що надходять із різних джерел, настільки колосальні, що протиріччя які виникають між збільшеними потоками інформації та організаційнотехнічними можливостями, які $є$ в наявності по їх збору, обробці, пошуку та використанню, зумовлюють необхідність розробки нових методів організації даних процесів. Одним із перспективних методів $€$ використання технології на базі концепції мережецентричних систем $[2 ; 6]$.

Аналіз останніх досліджень і публікацій. Головною особливістю мережецентричних систем є мережевий принцип їх побудови, який забезпечує максимальне розширення можливостей отримання інформації в рамках предметної області, доступу до неї, її розподілу та зворотного зв'язку. При цьому з технологічної точки зору мережецентричні системи передбачає наявність трьох взаємопов'язаних типових елементи [7-8]:

- інформаційних датчиків, що забезпечують генерування інформації в зоні відповідальності;

- засобів впливу на зовнішнє середовище, які забезпечують безпосередній вплив на об'єкти, що контролюються в зоні відповідальності;

- інформаційно-керуючих заходів, що реалізують функції зберігання і аналізу інформації, керування першими двома елементами, а також інформування осіб, що приймають рішення.

Іншою важливою відмінністю мережецентричної системи від систем інших класів являється те, що вихід з ладу одного або декількох ії вузлів не призводить до виходу з ладу всієї системи загалом. Тим самим мережецентричні системи сприяють створенню Єдиного інформаційного простору, що в 
свою чергу дозволить підвищити оперативність збору і обробки різних видів інформації, в тому числі і геопросторової [4; 9-10].

Проведений аналіз в [1-2;6] складу та структури геоданих, що оброблюються, свідчить про їх високу різнорідність.

Водночас існуюча технологія обробки геоданих в органах управління в більшості передбачає ручний режим роботи, а також відсутність єдиного інформаційного простору. Все це 3 урахуванням росту обсягів геоданих, які добуваються в процесі ведення розвідки, призводить до зниження оперативності їх обробки.

Таким чином, існуюча технологія обробки геоданих має такі недоліки:

- в процесі обміну даними між органами управління не передбачається взаємодії автоматизованих систем;

- в процесі обміну даними між органами управління не передбачається децентралізація;

- існує необхідність заповнення та подачі заявок в неавтоматизованому режимі для отримання необхідної інформації;

- виникає необхідність тривалого очікування обробки заявок і отримання необхідної інформації.

Мета статті. Розробка концепції створення розподіленої системи збору, обробки, зберігання і пошуку геопросторових даних при веденні геопросторової розвідки з типовою структурою геоданих, що обробляються.

\section{Виклад основного матеріалу}

Вимоги до складу геоданих, що оброблюються, залежать в першу чергу від завдань, які вирішуються користувачами в їх предметній області.

Способи вирішення даних завдань багато в чому визначаються реалізованими організаційнотехнічними умовами. В складі останніх важливу роль відіграють способи організації інформаційної взаємодії.

Відповідно до цього, в рамках проведених досліджень була розроблена концептуальна модель єдиного інформаційного простору збору, зберігання і пошуку геоданих, яка зображена на рис. 1.

Відмінною здатністю даної моделі являється використання територіально-розподіленої бази окремих каталогів геоданих та організації доступу до даних, що зберігаються в каталогах за допомогою інтеграційної платформи формування єдиного інформаційного простору.

При цьому остання відіграє роль сполучної ланки між вузлами територіально-розподіленої бази [1].

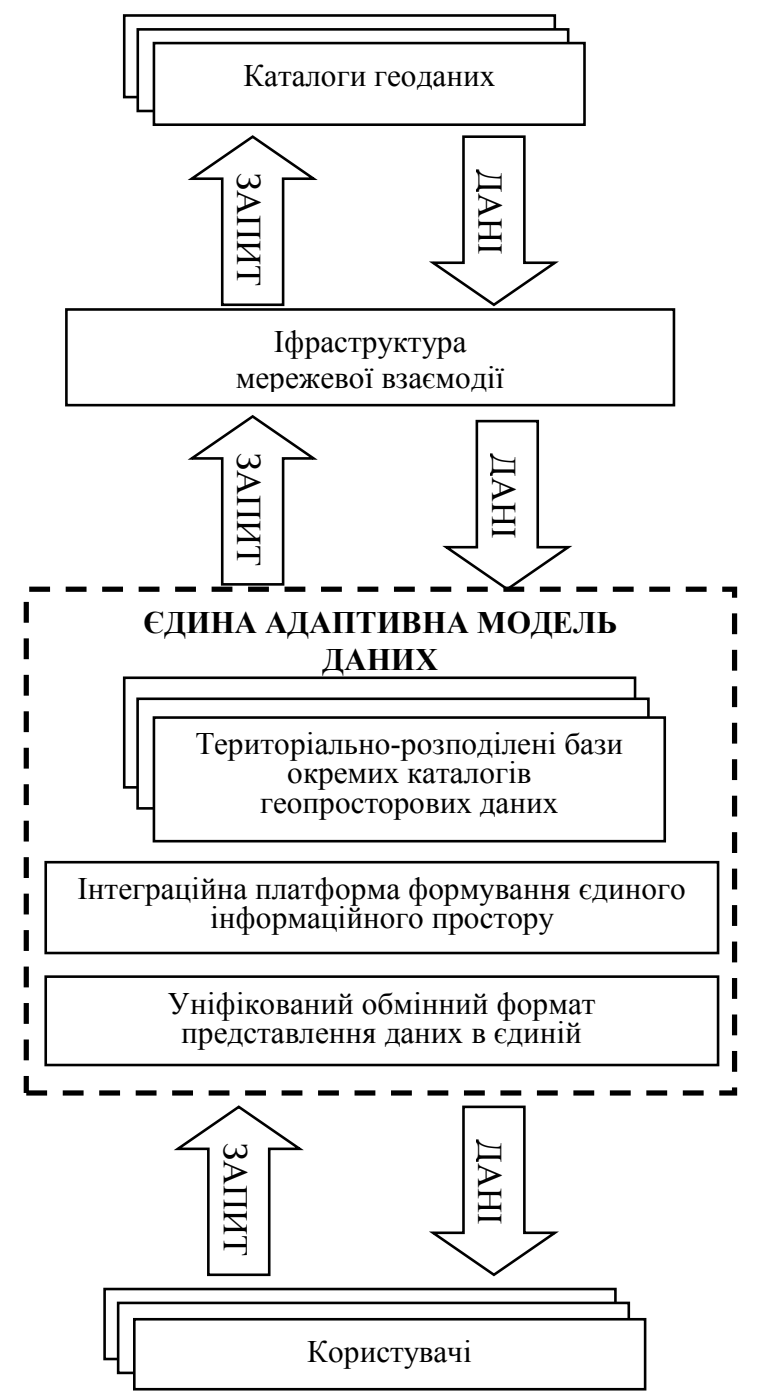

Рис.1. Концептуальна модель єдиного інформаційного простору збору, зберігання і пошуку геопросторових даних

На рис. 2 відображені вимоги до складу типового екземпляру даних, який адаптований для зберігання в територіально-розподіленій базі окремих каталогів.

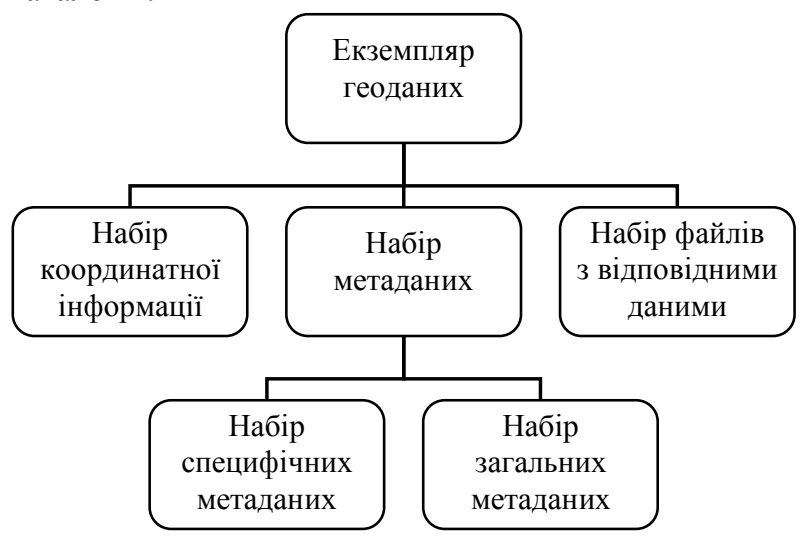

Рис. 2. Склад типового екземпляру геоданих для зберігання в територіально-розподіленій базі окремих каталогів 
В рамках даних вимог структуру та склад метаданих передбачається реалізувати із використанням сучасних стандартів. При цьому до складу метаданих необхідно додати набір специфічних метаданих, що розбиті на дві групи:

- інформація про склад об'єкту;

- інформація спеціального призначення іншим способом пов'язаної з екземпляром геоданих, який описується.

До складу першої групи повинна входити інформація про об'єкти управління (перелік яких ведеться у відповідних органах управління), тим чи іншим чином пов'язаних 3 екземпляром геоданих, що описується.

До складу другої групи повинні входити відомості, які забезпечують формування оптимальних пошукових запитів до каталогів геопросторових даних. Проведений в рамках даного дослідження аналіз існуючих методів розподіленого пошуку показав, що вони не враховують вказані особливості. Наприклад архітектура сервісу каталогу геопорталу Євросоюзу, що вирішує завдання інтеграції територіально-розподілених каталогів європейських організацій, які займаються створенням та розподіленням геопросторових даних, передбачає: сервіс розподіленого пошуку, який здійснює обробку запитів користувачів, лише перенаправляє ці запити усім пошуковим сервісам по окремим каталогам, після чого об'єднує результати їх виконання та видає їх користувачу. На рис. 3 представлені принципова схема складу та структури метаданих (загальних та специфічних).

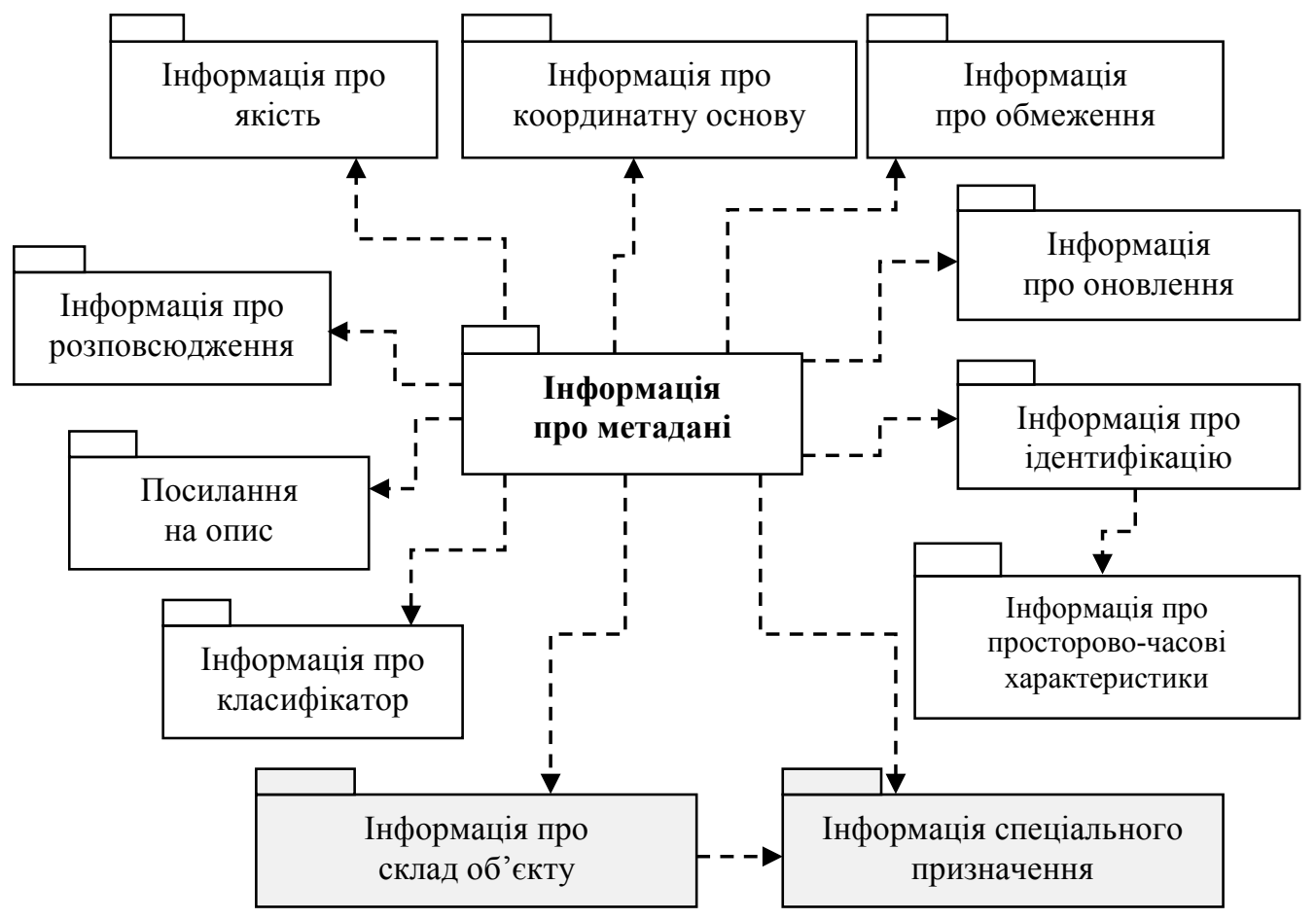

Рис. 3. Принципова схема складу і структури метаданих

До складу відомостей, що забезпечують операції пошуку геоданих в територіально-розподіленій базі (набір специфічних даних), повинні входити:

- дата останнього оновлення геоданих по заданому запиту;

- вузол територіально-розподіленої бази окремих каталогів, де зберігаються вхідні екземпляри геоданих;

- права доступу у відповідності 3 політиками розмежування доступу.

Таким чином, вказані вимоги, з одного боку, забезпечують уніфікацію геоданих, що зберігаються, а $з$ іншої - є основою для функціонування територіально-розподліеної бази окремих каталогів як основи мережецентричної системи.
Необхідність введення цієї групи метаданих обумовлена тим, що ефективність пошуку може бути підвищена, якщо при формуванні пошукових запитів буде врахована специфіка розподілу геопросторових даних в каталогах. Наприклад, багато космічних апаратів дистанційного зондування Землі передають в приймальний центр дані тільки на певну територію (режим безпосередньої передачі). У той же час $з$ деяких апаратів передача даних в різні центри виконується за регулярним розкладом.

Облік цих особливостей при виконанні розподіленого пошуку геопросторових даних дозволяє забезпечити ефективний розподіл пошукових запитів до каталогів.

Запит до каталогу може містити умови обмеження області пошуку, що призведе до значного 
зменшення навантаження на програмно-апаратні засоби центру і збільшить швидкість обробки запитів. 3 урахуванням представлених вимог пропону- ється наступний алгоритм пошуку необхідних геоданих в територіально-розподіленій базі окремих каталогів, схема якого наведена на рис. 4.

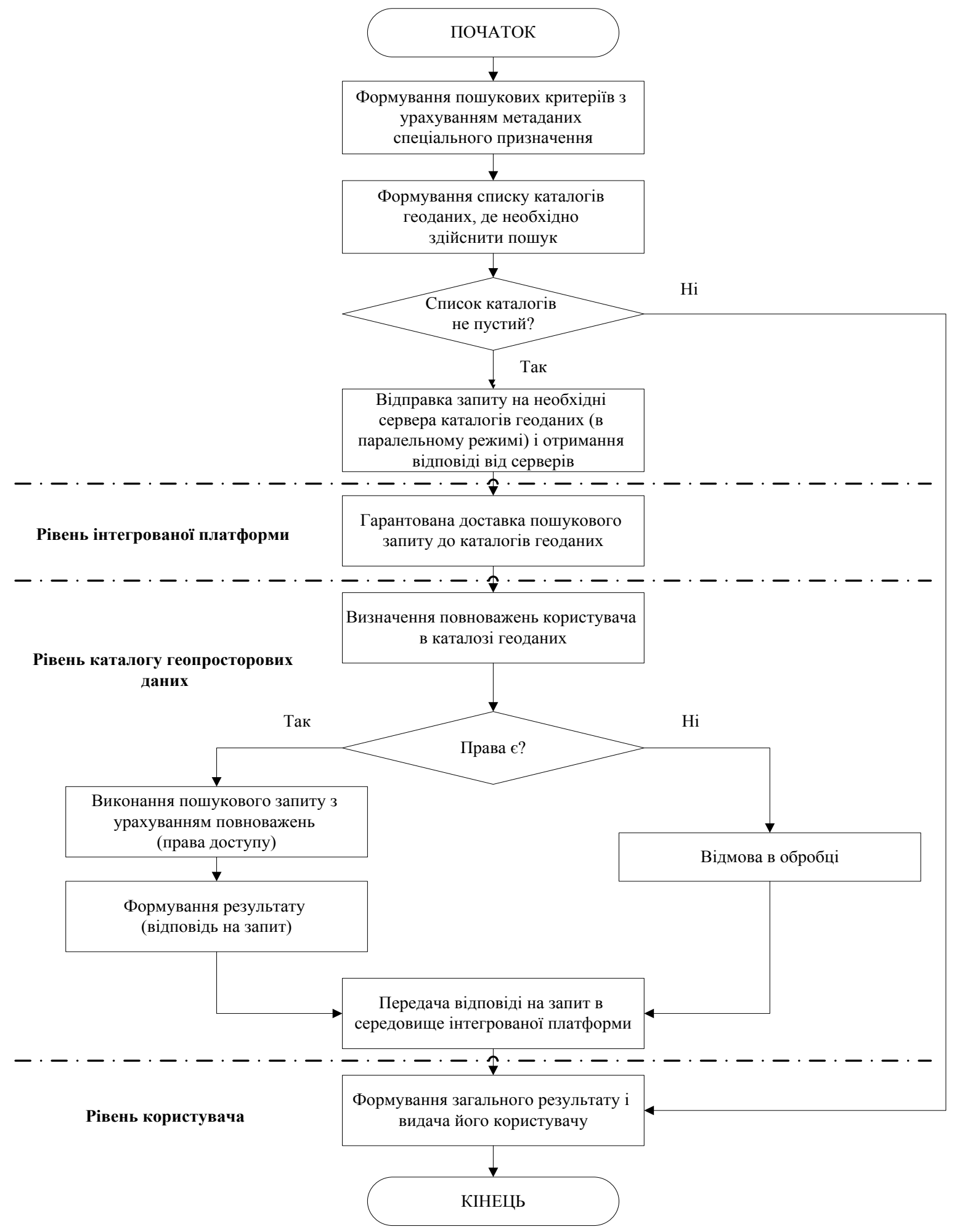

Рис. 4. Схема алгоритму пошуку необхідних геоданих в територіально-розподіленій базі даних

В даному алгоритмі можна виділити 3 рівні процесу пошуку необхідної інформації.

Рівень користувача. На даному рівні формуються критерії для відправки пошукового запиту 3 урахуванням метаданих спеціального призначення. Відбувається формування списку окремих каталогів геопросторових даних, які можуть містити необхідні відомості (відсікаються каталоги, які відомості,що 
шукаються точно не містять). Здійснюється відправка пошукових запитів на сервера каталогів з сформованого списку і перехід в режим очікування відповідей від них.

Коли відповіді від усіх опитаних серверів будуть отримані, відбувається формування загального результату виконання запитів і видача його користувачеві. Фактично даний етап гарантує, що навантаження на інфраструктуру мережевої взаємодії буде мінімально необхідною.

На другому рівні вирішується завдання управління використанням інформаційних ресурсів, яке полягає в тому, щоб на основі інформації про поточний стан бази даних надавати несуперечливий доступ до геопросторових даних.

Тому здійснюється управління доступом геопросторових даних за моделлю управління доступом до геопросторових даних [11-12].

Третій рівень складається з метапланувальника, геоданих та користувачів.

Якщо інформаційні потреби представлені комп'ютерами користувачів, а планувальник управляє розподілом геоданих між користувачами, то архітектура управління - однорівнева (рис. 5).

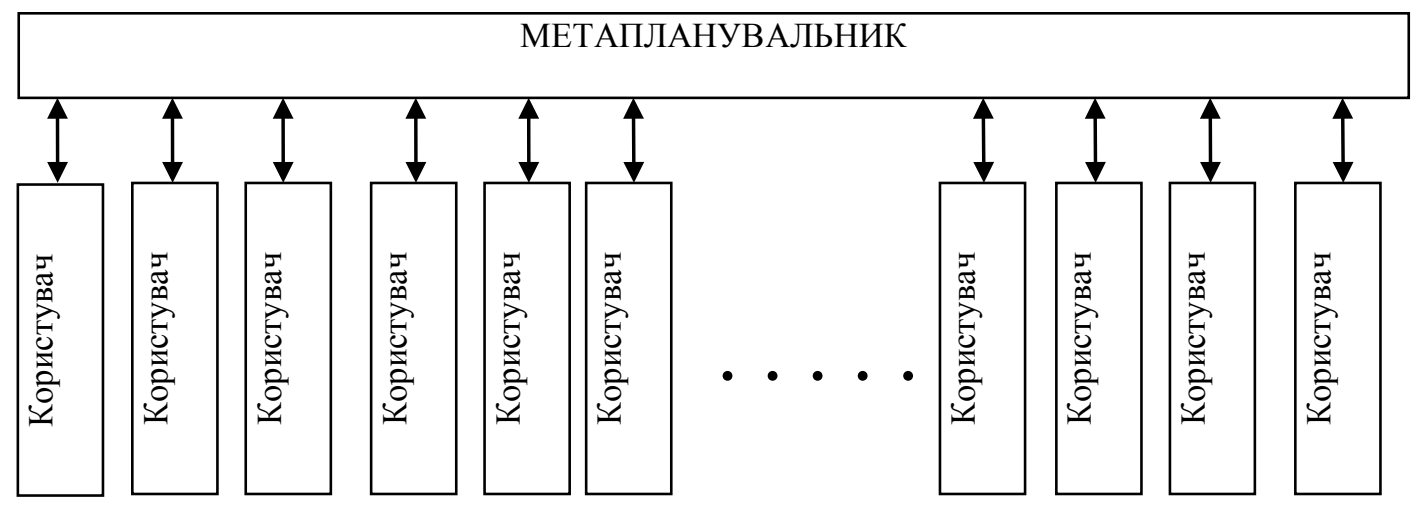

Рис. 5. Однорівнева архітектура управління розподілом геоданих

Якщо користувачі згруповані в обчислювальні вузли, а розподіл геоданих здійснюється спочатку метапланувальником серед обчислювальних вузлів (кластерів), а потім локальні планувальники здійснюють розподіл ресурсу серед користувачів кластера, то архітектура управління - дворівнева (рис. 6).

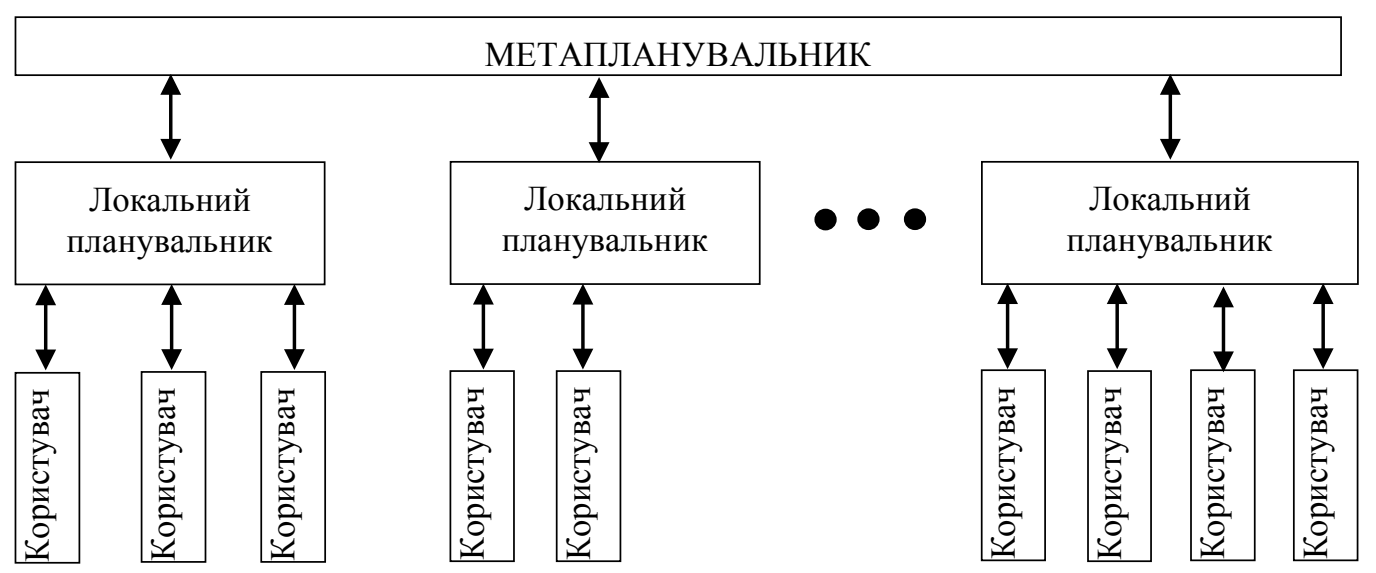

Рис. 6. Дворівнева архітектура управління розподілом геоданих

Задача управління використанням геопросторових даних полягає в тому, щоб на основі інформації про поточний стан бази даних надавати несуперечливий доступ. Ефективність управління оцінюється такими величинами, як: середній час очікування запитів до бази даних, інтенсивність відмов обслуговування запитів користувача до баз даних, інтенсивність споживання геопросторових даних користувачами, середня кількість вільного віртуального ресурсу.

В сучасних програмних пакетах реалізовано чотири політики розподілу ресурсів між незалежно працюючими користувачами:

- політика розділених ресурсів (передбачається компенсація користувачу за переспоживання чи недоспоживання віртуального ресурсу (у порівнянні 
3 обсягом віртуального ресурсу, на який претендує користувач за домовленістю) протягом певного часу);

- функціональна політика (компенсація не передбачається, а кожний користувач споживає віртуальний ресурс виключно в межах домовленості);

- політика "роботи до строку" (створюються пільгові умови для користувачів, які поспішають виконати визначений обсяг робіт до визначеного строку);

- політика явного виділення ресурсів (використовується “ручне управління” розподілом ресурсів у відповідності з пріоритетом користувачів.

В усіх запропонованих політиках користувач отримує дозвіл на використання ресурсу в залежності від наданої йому за домовленістю квоти на використання ресурсу, що визначається часткою віртуального ресурсу, на яку претендує користувач, або пріоритетом користувача на використання ресурсу [13].

Нехай до бази даних право доступу на використання геопросторових даних має певна кількість користувачів. На програмному рівні прописується квота, що дорівнює відсотку загального ресурсу, на який претендує користувач. Справедливою вважається така квота, яка дорівнює внеску віртуального ресурсу користувача у відсотках від загального обсягу. Але в кожний момент часу не всі користувачі активні. Отже, загальний ресурс розподіляється “планувальником" тільки між активними користувачами. Розподіл між активними користувачами здійснюється пропорційно їх квотам. Тому, якщо користувач має внесок $20 \%$ у загальний ресурс, але в поточний момент часу активним є тільки він один, то він заволодіває усім віртуальним ресурсом.

Розподіл ресурсів здійснюється на програмному (логічному) рівні “планувальником” на визначений інтервал часу. “Планувальник” розподіляє віртуальні ресурси виходячи із співвідношення кількості запитів від користувачів на доступ до бази даних. Для кожного користувача підраховується усереднене фактичне використання віртуального ресурсу, i якщо воно перебільшує (або зменшує) надану квоту, то спрацьовує механізм компенсації пере- (недо-) споживання віртуального ресурсу. Тобто, якщо користувач певний час не використовував ресурс, то його компенсаційний коефіцієнт збільшився, і він має право отримати більшу частину віртуального ресурсу. Якщо завдання (запити), які захопили ресурс (раніше інших завдань), використовують ресурс більше наданої квоти, то користувач лишається права отримати певну кількість квитків.

Загалом на програмному рівні, в залежності від маршрутизації звернення користувачів до баз даних можна виділити два способи організації управління доступом до геопросторових даних:
- однорівневий - “планувальник” здійснює розподіл віртуальних ресурсів надання доступу до баз даних між рівноправними та/або наділеними певним пріоритетом користувачами інформації;

- дворівневий - віртуальні ресурси надання доступу до баз даних згруповані у вузли, а власне розподіл ресурсів здійснюється спочатку “метапланувальником” серед обчислювальних вузлів (кластерів) підсистеми, а потім локальні “планувальники" здійснюють розподіл ресурсів серед користувачів кластера (рис. 1-2).

“Метапланувальник” безпосередньо взаємодіє 3 апаратними ресурсами серверу баз даних та вузлами (“локальними планувальниками”). Через локальних “планувальників" “мета планувальник” надає доступ користувачам до баз даних. "Метапланувальник” та локальні “планувальники” забезпечують синхронізований та несуперечливий доступ та використання користувачами інформаційних ресурсів.

Нехай $\mathrm{N}$ кількість користувачів $U=\{i\}|U|=\mathrm{N}$ об'єднані дворівневим способом організації управління доступом до геоданих. Сума віртуальних ресурсів користувачів дорівнює віртуальному ресурсу всієї системи: $S=\sum_{i} S_{i}$. Здатність геоданих, як інформаційного ресурсу вимірюється, наприклад, в одиницях MIPS (Million Instruction Рег Second). Отже, кожний $i$-й користувач має внесок до геоданих, який вимірюється часткою:

$$
p_{i}=\frac{S_{i}}{S}, \sum_{i} p_{i}=1 .
$$

Якщо спосіб організації управління доступом однорівневий, то користувачі мають доступ до віртуального ресурсу, і приведена частка представляє квоту користувача системи. Якщо система дворівнева, то користувачі мають доступ до віртуального ресурсу через вузли, що представляють в загальному випадку як кластери (локальні об'єднання користувачів), так і окремих користувачів. Будемо вважати, що множина користувачів $U=\{i\}$ складається 3 підмножини $U_{j} \mid \bigcup_{j} U_{j}=U, \bigcap_{j} U_{j}=\varnothing$. Тобто кожен користувач належить одній і тільки одній підмножині $U_{j}: i \in U_{j}$, що відповідає вузлу територіальнорозподіленої бази даних.

Здатність віртуального ресурсу вузла бази даних $C_{j}=\sum_{k \in U_{j}} S_{k}, j=1, \ldots K$.

Оскільки у дворівневій архітектурі управління розподілом геоданих користувач має доступ до геоданих через посередництво кластера, то представимо квоту використання ресурсу користувача (1) в такому вигляді: 


$$
p_{i}=\frac{S_{i}}{C_{j}} \frac{C_{j}}{S}
$$

Частка $\frac{C_{j}}{S}$ представляє квоту вузла віртуального ресурсу:

$$
r_{j}=\frac{C_{j}}{S}, \sum_{j} r_{j}=1 .
$$

Користувач вузла бази даних має квоту на використання обчислювальних ресурсів вузла, пропорційну його внеску в обчислювальний ресурс вузла:

$$
q_{j}=\frac{S_{j}}{C_{j}}, \sum_{i} q_{i}=1
$$

Отже квота (2) приймає вигляд:

$$
p_{i}=\left\{\begin{array}{l}
q_{i} \cdot r_{j}, i \in U_{j}, \\
0, i \notin U_{j} .
\end{array}\right.
$$

Користувач може знаходитись в активному стані і пасивному. Зміна стану відбувається з інтервалами часу, визначеними випадковою величиною 3 відомим законом розподілу. Позначимо множину активних користувачів $A \subseteq U$. Активні користувачі отримують доступ до віртуального ресурсу пропорційно своій квоті:

$$
x_{i}=\frac{p_{i}}{\sum_{i \in A} p_{i}}, \sum_{i} x_{i}=1
$$

Частка доступного віртуального ресурсу у випадку однорівневого способу організації управління доступом розраховується за формулою:

$$
\forall i \quad x_{i}=\left\{\begin{array}{l}
\frac{p_{i}}{\sum_{i \in A} p_{i}}, i \in A, \\
0, i \notin A,
\end{array}\right.
$$

де $A \subseteq U$ - підмножина активних користувачів геопорталу.

Якщо архітектура управління розподілом геоданих дворівнева, то частка доступного ресурсу розраховується 3 урахуванням активності вузла бази даних (вузол активний, якщо хоч один його користувач активний):

$$
\begin{gathered}
\forall i \in U, j \in K \quad x_{i}= \\
=\left\{\begin{array}{l}
\frac{q_{i}}{\sum_{i \in A \cap U_{j}} p_{i}} \cdot \frac{r_{j}}{\sum_{j \in K_{A}} r_{j}},(i \in A) \wedge\left(i \in U_{j}\right), \\
0,(i \notin A) \vee\left(i \notin U_{j}\right),
\end{array}\right.
\end{gathered}
$$

де $K_{A} \subseteq K$-підмножина усіх активних вузлів, $A \bigcap U_{j}$ - підмножина активних користувачів вузла, до якого належать користувачі $i$.

Обсяг доступного віртуального ресурсу корис-

$$
\begin{aligned}
& \text { тувача } \quad Z_{i}=x_{i} \cdot S . \quad \text { дорівнює } \quad \text { Оскільки } \\
& \sum_{i} x_{i}=1, m o \sum_{i} Z_{i}=S .
\end{aligned}
$$

Користувач, якщо він активний, генерує запити до баз даних, які вимагають для свого виконання певний обсяг віртуального ресурсу, і розміщує їх у буфері запитів. Запит, який знаходиться у буфері запитів, очікує дозволу від "планувальника" на захоплення віртуального ресурсу 3 метою надання доступу до відповідних баз даних. Оскільки буфер запитів користувача обмежений, то запит може отримати відмову. На початку кожного такту “планування" запиту, обсяг вимоги віртуальних ресурсів яких не перевищує обсяг доступного віртуального ресурсу користувача $Z_{i}$, отримують дозвіл на захоплення віртуального ресурсу і захоплюють ресурс на час, рівний тривалості виконання запиту.

Локальний “планувальник” отримує від "мета планувальника" інформацію про частку доступного віртуального ресурсу $r_{j}$ на надання доступу до баз даних на поточний такт управління, а від користувачів - інформацію про поточний стан користувача. Локальний “планувальник” розподіляє доступний віртуальний ресурс вузла $\frac{r_{j}}{\sum_{j \in K_{A}} r_{j}} \cdot S$ між усіма своїми активними користувачами $i \in U_{j} \cap A$ :

$$
\forall i \in K_{A} \quad \frac{r_{j}}{\sum_{j \in K_{A}} r_{j}} \cdot S=\sum_{i \in U_{j} \cap A} Z_{i} .
$$

Якщо у буфері завдань користувача $є$ завдання, обсяг потреби ресурсу якого не перевищує обсяг доступного ресурсу користувача, то користувач отримує дозвіл на отримання ресурсу. Ясно, що швидше доступ отримають користувачі, які переглядаються планувальником “у першу чергу". Звідси локальний планувальник переглядає користувачів у порядку спадання значення пріоритету користувача. Очевидно, що від пріоритетів сильно залежить використання ресурсу.

Наприклад, якщо користувачі 3 маленькими потребами ресурсу стоять у черзі першими, то користувачі з великими потребами ресурсу так і не отримають дозвіл на використання ресурсу через його недостатність. Звідси слідує, що інформація про потік завдань від користувача необхідна для ефективного управління розподілом ресурсів. Замість пріоритетів може реалізовуватись також перегляд користувачів у випадковому порядку. У випадках, коли потік завдань змінюється в часі, такий спосіб може бути більш ефективним, ніж пріоритети користувачів.

Рівень інтегрованої платформи. На даному рівні інтегрована платформа формування єдиного ін- 
формаційного простору забезпечує гарантовану доставку пошукового запиту на всі вузли територіально-розподіленої бази окремих каталогів, що функціонують в рамках мереже центричної системи, а також повернення відповіді від них користувачеві. Гарантованість доставки забезпечується шляхом застосування спеціального програмного забезпечення, реалізованого авторами.

Рівень каталогу геопросторових даних. На даному рівні забезпечується виконання пошукових запитів на всіх функціонуючих вузлах територіально-розподіленої бази окремих каталогів геопросторових даних і відправка результатів споживачеві. Відправлення здійснюється за допомогою інтеграційної платформи.

\section{Висновки}

В статті розроблена концепція створення розподіленої системи збору, обробки, зберігання і по- шуку геопросторових даних при веденні геопросторової розвідки. Запропонований склад геоданих, а також алгоритм їх пошуку з використанням територіально-розподіленої бази окремих каталогів. Розроблена модель управління доступом до геоданих в територіально-розподіленій базі даних, що передбачає зниження часових витрат на пошук інформації в процесі розробки звітних інформаційних документів.

Реалізація розроблених підходів дозволить підвищити оперативність і обгрунтованість прийняття управлінських рішень в процесі ведення геопросторової розвідки.

Напрямками подальших досліджень авторів $\epsilon$, розроблення прототипу автоматизованої інформаційної системи (AIC) збору, обробки та аналізу різнорідних просторових даних, яка реалізує представлені в статті підходи. Використання АІC дозволило підвищити оперативність геопросторової розвідки в інтересах прийняття управлінських рішень.

\section{Список літератури}

1. Визначення та основні поняття геопросторової розвідки / І.А. Кухарський, В.О. Подліпаєв, О.В. Атрасевич, В.О. Шумейко // Системи обробки інформації: збірник наукових праць. - 2013. - № 6(113). - С. 96-98.

2. Подліпаєв В.О. Геопросторова розвідка, як шлях реалізації геоінформаційного підходу у комплексній обробці розвідувальної інформації / В.О. Подліпаєв // Системи обробки інформації. - 2013. - № 5(112). - С. 53-55.

3. Ладанюк А.П. Системний аналіз складних систем управління / А.П. Ладанюк, Я.В. Смітюх, Л.О. Власенко. - К.: НУХТ, 2013. $-274 \mathrm{c}$.

4. Калашніков С.М. Аналіз характеру сучасних воєнних конфліктів / С.М. Калашніков, С.С. Гаценко, А.В. Шишацький // Збірник матеріалів міжнародної науково-практичної конференції “Виклики гібридної війни: інформаційний вимір". - Вільнюс, 16-17 серпня 2019 р. - С. 24-27.

5. Попов М.О. Геопросторова розвідка в операціях збройних сил / М.О. Попов // Наука і оборона. - 2010. - № 2. C. $30-40$.

6. Development of a method of fuzzy evaluation of information and analytical support of strategic management / I. Alieinykov, K.A. Thamer, Y. Zhuravskyi, O. Sova, N. Smirnova // Eastern-European Journal of Enterprise Technologies. 2019. - № 2(102). - P. 16-27. https://doi.org/10.15587/1729-4061.2019.184394.

7. Method of integral estimation of channel state in the multiantenna radio communication systems / S. Kalantaievska, H. Pievtsov, O. Kuvshynov, A. Shyshatskyi, S. Yarosh // Eastern-European Journal of Enterprise Technologies. - 2018. № 9(95). - P. 60-76. https://doi.org/10.15587/1729-4061.2018.144085.

8. Щерба А.А. Еволюція розвідувально-вогневої технології на основі мережецентричних принципів управління / А.А. Щерба // Вісник Хмельницького національного університету. - 2014. - № 4. - С. 109-112.

9. Гаценко С.С. Проблема розподілу інформаційних потоків в автоматизованих системах управління військами (силами) Збройних Сил України / С.С. Гаценко, Ю.М. Кальницький, О.М. Гельвейчук // Збірник наукових праць Центру воєнно-стратегічних досліджень. - 2014. - № 2(51). - С. 107-111.

10. Савин Л.В. Сетецентричная и сетевая война. Введение в концепцію / Л.В. Савин. - М.: Евразийское движение, 2011. $-130 \mathrm{c}$.

11. Кондратьев А.А. Сетецентрический фронт. Боевые действия в едином информационном пространстве / А.А. Кондратьев // Национальная оборона. - 2011. - № 2. - С. 47-53.

12. Тактико-технічні вимоги до геопорталу Збройних Сил України. Звіт про НДР шифр “Провідник” заключний: ГУОЗ ЗСУ. - К.: 2016. - 151 с.

13. Степенко І.В. Моделювання управляючих систем засобами мереж Петрі з інформаційними зв'язками / I.В. Степенко // Вісник Черкаського державного технологічного університету. - 2011. - № 3. - С. 3-9.

\section{References}

1. Kukhars'kii, I.A., Podlipayev, V.O., Atrasevich, O.V. and Shumeiko, V.O. (2013), "Viznachennya ta osnovni ponyattya geoprostorovoï rozvidki" [Definition and basic concepts of geospatial intelligence], Information Processing Systems, No. 6(113), pp. 96-98.

2. Podlipaiev, V.O. (2013), "Heoprostorova rozvidka, yak shliakh realizatsii heoinformatsiinoho pidkhodu u kompleksnii obrobtsi rozviduvalnoi informatsii" [Geospatial intelligence as a way to implement the geoinformation approach in the integrated processing of intelligence information] Information Processing Systems, No. 5(112), pp. 53-55. 
3. Ladaniuk, A.P., Smitiukh, Ya.V. and Vlasenko, L.O. (2013), "Systemnyi analiz skladnykh system upravlinnia" [System analysis of complex control systems], NUKhT, Kyiv, 274 p.

4. Kalashnikov, Ye.M., Hatsenko, S.S. and Shyshatskyi, A.V. (2019), Analysis of the nature of modern military conflicts, Collection of Proceedings of the International Scientific and Practical Conference "Challenges of Hybrid War: An Information Dimension", 16-17 August, Vilnius, Lithuania, pp. 24-27.

5. Popov, M.O. (2010), "Heoprostorova rozvidka v operatsiiakh zbroinykh syl" [Geospatial intelligence in military operations], Science and Defense, No. 2, pp. 30-40.

6. Alieinykov, I., Thamer, K.A., Zhuravskyi, Y., Sova, O. and Smirnova, N. (2019), Development of a method of fuzzy evaluation of information and analytical support of strategic management, Eastern-European Journal of Enterprise Technologies, No. 2(102), pp. 16-27, https://doi.org/10.15587/1729-4061.2019.184394.

7. Kalantaievska, S., Pievtsov, H., Kuvshynov, O., Shyshatskyi, A. and Yarosh, S. (2018), Method of integral estimation of channel state in the multiantenna radio communication systems, Eastern-European Journal of Enterprise Technologies, No. 9(95), pp. 60-76, https://doi.org/10.15587/1729-4061.2018.144085.

8. Shcherba, A.A. (2014), "Evoliutsiia rozviduvalno-vohnevoi tekhnolohii na osnovi merezhetsentrychnykh pryntsypiv upravlinnia" [The evolution of reconnaissance and fire technology based on network-centric management principles], Bulletin of the Khmelnitsky National University, No. 4, pp. 109-112.

9. Hatsenko, S.S., Kalnytskyi, Yu.M. and Helveichuk, O.M. (2014), "Problema rozpodilu informatsiinykh potokiv v avtomatyzovanykh systemakh upravlinnia viiskamy (sylamy) Zbroinykh Syl Ukrainy" [The problem of the distribution of information flows in automated command and control systems of the Armed Forces of Ukraine], Collection of Scientific Papers of the Center for Military Strategic Studies, No. 2 (51), pp. 107-111.

10. Savin, L.V. (2011), "Setetsentrichnaya i setevaya voina. Vvedenie v kontseptsiyu" [Network-centric and network war. Introduction to the concept], Evraziiskoe dvizhenie, Moscow, $130 \mathrm{p}$.

11. Kondrat'ev, A.A. (2011), "Setetsentricheskii front. Boevye deistviya v edinom informatsionnom prostranstve" [Network-centric front. Fighting in a single information space], National Defense, No. 2, pp.47-53.

12. Main Directorate of Operational Support of the Armed Forces of Ukraine (2016), "Taktyko-tekhnichni vymohy do heoportalu Zbroinykh Syl Ukrainy. Zvit pro NDR shyfr "Providnyk" zakliuchnyi" [The performance characteristics of the geoportal of the Armed Forces of Ukraine. Report on research code "Explorer" final], Kyiv, 151 p.

13. Stepenko, I.V. (2011), "Modeliuvannia upravliaiuchykh system zasobamy merezh Petri z informatsiinymy zviazkamy" [Modeling control systems using Petri nets with information connections], Bulletin of Cherkasy State Technological University, No. 3, pp. 3-9.

\section{Відомості про авторів:}

\section{Лященко Руслан Вікторович}

старший науковий співробітник

Харківського національного університету

Повітряних Сил ім. І. Кожедуба,

Харків, Україна

https://orcid.org/0000-0001-6169-5799

Кузнєцов Дмитро Олександрович слухач Національного університету оборони України ім. І. Черняховського, Київ, Україна https://orcid.org/0000-0003-2749-7013

\section{Повещенко Олексій Васильович} слухач Національного університету оборони України ім. І. Черняховського, Київ, Україна

https://orcid.org/0000-0001-5846-464X

\section{Козін Василь Вікторович}

слухач Національного університету оборони України ім. І. Черняховського, Київ, Україна

https://orcid.org/0000-0002-3978-571X

Стасенко Дмитро Володимирович слухач Національного університету оборони України ім. І. Черняховського, Київ, Україна

https://orcid.org/0000-0003-0801-0011
Information about the authors:

\author{
Ruslan Lyaschenko \\ Senior Research \\ of Ivan Kozhedub Kharkiv \\ National Air Force University, \\ Kharkiv, Ukraine \\ https://orcid.org/0000-0001-6169-5799
}

\section{Dmytro Kuznietsov}

Student of the National Defence University of Ukraine named after Ivan Cherniakhovskyi,

Kyiv, Ukraine

https://orcid.org/0000-0003-2749-7013

\section{Oleh Poveshchenko}

Student of the National Defence University of Ukraine named after Ivan Cherniakhovskyi,

Kyiv, Ukraine

https://orcid.org/0000-0001-5846-464X

\section{Vasyl Kozin}

Student of the National Defence University of Ukraine named after Ivan Cherniakhovskyi,

Kyiv, Ukraine.

https://orcid.org/0000-0002-3978-571X

Dmitrii Stasenko

Student of the National Defence University of Ukraine named after Ivan Cherniakhovskyi,

Kyiv, Ukraine

https://orcid.org/0000-0003-0801-0011 


\title{
РАСПРЕДЕЛЕННАЯ СИСТЕМА СБОРА, ОБРАБОТКИ, ХРАНЕНИЯ И ПОИСКА ГЕОПРОСТРАНСТВЕННЫХ ДАННЫХ ПРИ ВЕДЕНИИ ГЕОПРОСТРАНСТВЕННОЙ РАЗВЕДКИ
}

\author{
Р.В. Лященко, Д.А. Кузнецов, О.В. Повещенко, В.В. Козин, Д.В Стасенко
}

Рассматриваются особенности сетецентрической систем, повышающих эффективность процессов сбора, хранения и поиска геопространственных данных при ведении геопространственной разведки, как прогрессивного и перперспективная технического вида военной разведки Украины. Разработана концептуальная модель единого информационного пространства сбора, хранения и поиска геопространственных данных. Предложено типичную структуру геопо-росторових данных, обрабатываемых в территориально-распределенных базах. Разработанный алгоритм распределенного поиска геоданных в каталогах с моделью управления доступом к геопространственных данных.

Ключевые слова: базы данных, геоданные, геопространственная разведка, сетецентрическая система, метаданные.

\section{DISTRIBUTED SYSTEM OF COLLECTION, PROCESSING, STORAGE AND SEARCH OF GEOGRAPHICAL DATA IN THE PERFORMANCE OF GEOPATRIC EXPLORATION}

\author{
R. Lyaschenko, D. Kuznietsov, O. Poveshchenko, V. Kozin, D. Stasenko
}

High rates of modern development of space facilities and technologies of remote sensing of the Earth contribute to the widespread use of geospatial data in solving various problems. The Armed Forces of Ukraine is developing geospatial intelligence that processes data obtained from different sources using a geoinformation approach, the essence of which is to systematize and integrate information about an object of intelligence obtained from different sources and display it in a single space-time coordinate system. The composition of the information needed to make a decision is increasingly reminiscent of a multi-level pie to which additional layers (layers) - the types of data used - are constantly added. In addition to terrain data, there is a growing flow of unstructured or poorly constructed information used in the decision making process that needs to be analyzed and taken into account. An analysis of the nature of contemporary military conflicts indicates that the main type of data being processed is geospatial data. It can be argued that 80 percent of information resources are linked. Geospatial data means data about geographic features that are formalized digital models of material or ideal (abstract) objects of the real or virtual world. A complete digital description of the spatial object and the content of the spatial data consists of the object identifier, a set of its attributes (properties, characteristics) with their values, and the location parameters of the object in space and time (in some space-time coordinate systems). The rules of digital modeling of reality objects are called spatial data model by describing the types and properties of elementary spatial objects, their sets and inter-object relations. To date, the volumes of geospatial data coming from different sources are so enormous that the contradictions that arise between the increased flow of information and the organizational and technical capabilities available to collect, process, search and use them make it necessary to develop new methods organization of these processes. One promising method is to use technology based on the concept of networkcentric systems. The features of network-centric systems that increase the efficiency of geospatial data collection, storage, and retrieval while conducting geospatial intelligence as a progressive and promising technical form of military intelligence are considered in the article. A conceptual model of a single information space for the collection, storage and search of geospatial data has been developed. A typical structure of geospatial data processed in geographically distributed databases is proposed. The algorithm of distributed location search in directories with model of access to geospatial data is developed.

Keywords: network centric systems, geospatial exploration, geodata, metadata, databases. 